doc. ThDr. Peter Borza, PhD.

UP v Prešove

\title{
Premeny Baziliky Zosnutia Presvätej Bohorodičky v Lutine
}

\begin{abstract}
The dominant feature of the Greek Catholic Marian pilgrimage site in Slovakia is Lutina's Dormition of the Mother of God Basilica. During her more than a hundred years of history it has undergone several modifications to the form as we know it today. The cause of the construction and transformation is not only the need for local believers and its technical condition, but from the beginning it was the need of pilgrims. Just miraculous events and incoming pilgrims led to the parish transshipment from Hanigovce to Lutina, building a chapel in the late 19th century and a new church in Lutina, which was in the years 2006-2009 rebuilt into a three-aisled basilica and is the largest Greek Catholic Marian shrine in Slovakia.
\end{abstract}

Key words: Lutina, Greek Catholic, Slovakia

Mariánske pútnické miesto Gréckokatolíckej cirkvi na Slovensku v L'utine sa teší čoraz väčšej oblube a záujmu verejnosti. Zmenená tvár pútnického areálu a sakrálnych pamiatok pozýva k návšteve čoraz väčší počet pútnikov, ale aj turistov obdivujúcich zaujímavé miesta Slovenska.

Lutina medzi takéto miesta rozhodne patrí už od polovice 19. storočia, ked' v roku 1852 došlo v Lutine k zázračným udalostiam, ktoré 
neskôr viedli k založeniu pútnického miesta. Dátovanie zázračných udalostí bolo vo viacerých publikáciách a článkoch uverejnených po roku 1968 uvádzané nesprávne a jednotlivými autormi navzájom preberané. ${ }^{1}$ Priebežne realizovaný výskum histórie pútnického miesta v Lutine priniesol nové poznatky, ktoré vyplývajú $\mathrm{z}$ archívnych prameňov a publikovaných príspevkov do roku 1950 a je základnou úlohou historika ich po náležitom kritickom skúmaní zverejnit a tým upresnit’ historické skutočnosti.

Základným dokumentom, ktorý datuje udalost̉ zjavení v L'utine do roku 1852 je Inventár farností Hanigovce. Z inventára sa dozvedáme, že k zjaveniam došlo vo sviatok sv. proroka Eliáša. ${ }^{2}$ Miestna veriaca Zuzana Fekete išla po sv. liturgii zbierat' huby. Ked’ už mala nazbieraných vela húb, tak sa vracala domov a na okraji lesa uvidela starca v nezvyčajnom svetle. Muž bol odetý do bieleho rúcha a na hrudi mal jasný kríž. S milým výrazom v tvári ju upozornil na jej najtajnejšie skutky a dal jej príkaz aby obyvatelom dediny odovzdala napomenutie v zmysle, aby prestali urážat Pána Boha a svätili nedelu a sviatky. Po týchto slovách zmizol. O niekolko týždňov prišla jej 13-14 ročná dcéra za Zuzanou do chrámu na sv. liturgiu v nedelu, aby prišla za týmto tajomným mužom. Zopakoval znova pôvodné slová a prikázal aby na mieste prvého zjavenia postavili svätý kríž. Po tomto druhom zjavení sa už

1 PAPP, š.: Lutinská udalost'. In: Slovo - mesačník gréckokatolíkov v ČssR. Trnava: ssv Trnava v CN Bratislava, 1988, roč. 20, č. 8, s. 8-12; Dejiny pútnického miesta Lutina. Bratislava: NOvUm 1991, 30 s.; DANCÁK, F.: Gréckokatolícke pútnické miesta na Slovensku. Prešov: Petra 2007. 75 s; BORZA, P.: Mariánske pútnické miesto Lutina od roku 1851 dodnes. In: Mariánske pútnické miesta Prešovskej gréckokatolíckej metropolie. Zost. Jana Koprivňáková. Prešov: GTF PU 2008, s. 30-36; PETRík, L.: Tisíce pútnikov prišlo do Lutiny na pút a posviacku baziliky. In: Slovo - časopis gréckokatolíckej cirkvi. 2009, roč. 41, č. 18-19, s. 7-8; DANCÁK, F.: Lutina. Bazilika a hora. Prešov: PETra, n. o. 2010, 128 s.; BorzA, P.: Mariánska svätyňa gréckokatolíkov v Lutine. In: Dom Pána. Zost. Jerzy Brusiło, Peter Tirpák, Marek Petro. Kraków-Prešov 2011, s. 115-130.

2 Archív Gréckokatolíckeho arcibiskupstva Prešov (dalej AGAP), fond (dalej f) Inventáre farností, inventárne číslo (dalej inv. č.) 930, Inventár farnosti Hanigovce $\mathrm{z}$ roku 1855. 
žena nemohla zdržat' a všetko rozpovedala kňazovi Štefanovi Rojkovičovi ako aj obyvatelom dediny. Nikto jej však neveril a ona sa stala predmetom žartov. O niekol'ko dní neskôr, ráno pred východom Slnka, stála na dvore svojho domu a znova už tretí raz uvidela to isté zjavenie. Milým hlasom jej pripomenul, prečo ešte nesplnila jeho požiadavku. Žena so slzami v očiach povedala, že ona všetko vykonala ako jej prikázal, ale obyvatelia dediny jej neuverili. Zjavenie vtedy žene povedalo: Nakolko mojim jednoduchým slovám neverili, tak ešte pred východom Slnka onemieš, ale neupadaj do zúfalstva a maj nádej v Boha. Dané proroctvo sa na žene vyplnilo a trvalo až do 23. novembra 1852, ked' na mieste prvého zjavenia bol postavený a posvätený svätý kríž. Vtedy prehovorila a zjavila Božiu vôlu aby v blízkostí kríža bola vybudovaná kaplnka zasvätená Matke Božej. Zuzane už všetci uverili a podujali sa na tom mieste vybudovat malý chrám. ${ }^{3}$ Umelecké stvárnenie udalosti predložil Mikuláš Štefan Dzurinda v zbierke piesní Lucinskaja Zorja z roku 1946. Môžeme ju pokladat za najstaršie známe publikované dielo venované L'utine v ktorom autor okrem piesní podáva aj veršované rozprávanie o dejinách mariánskeho odpustu v Lutine. ${ }^{4}$

Klasicistickú kaplnku Zosnutia Presvätej Bohorodičky postavili gréckokatolícki veriaci z Lutiny a Olejnikova na mieste, ktoré vyznačila Zuzane Fekete. Cirkevné schválenie vydal prešovský biskup Jozef Gaganec (1843-1875) listom zo dňa 16. novembra 1853. Kaplnka bola dokončená v roku 1854 vd’aka obetavosti kurátorov, ktorí putovali cez Viedeň, Budín, Transylvániu a Podkarpatsko, pričom zbierali prostriedky na vybudovanie spomínanej kaplnky. Začalo velké putovanie veriacich celého Uhorska, Sedmohradska a Halíča. Každý prinášal so sebou kamene, z ktorých potom postavili kaplnku a oporný múr pod ňou. V predvečer sviatku Zosnutia Presvätej Bohorodičky dňa

3 AGA Prešov, f. Inventáre farností, inv. č. 930, Inventár farnosti Hanigovce z roku 1855; Tiež: SABAdoš, M.: Naša Lucina.... In: Kalendár Blahovistnika na rok 1947. Prešov 1946, s. 109-113.

4 Dzurinda, š. M.: Lucinskaja Zorja. Prešov 1946, 40 s. 
27. augusta 1854 kaplnku posvätil biskupom J. Gagancom poverený kanonik Jozef Šoltys. ${ }^{5}$

Jednolodovú kamennú stavbu tvorí štvorcový priestor s polkruhovým uzáverom, v ktorom je umiestnené okrúhle okno. Kaplnka má dva vchody. Nad hlavným je umiestnená malá strešná vežička so zvonom a nad bočným je svetlík v podobe termového okna. ${ }^{6}$ Interiéru dominuje klasicistický oltár s obrazom na plátne, ktorý predstavuje Nanebovzatie Panny Márie. Súčastou interiéru je aj bočný oltár s obrazom Ježiša Krista modliaceho sa v Getsemanskej záhrade predvečer svojho ukrižovania. Kaplnka slúžila pre pútnikov od roku 1854 a slávnostné liturgie sa slávili pred jej vchodom. Počas homílie kazatel’ vystúpil vnútorným schodiskom na balkón, ktorý bol postavený nad hlavným vchodom a odtial prednášal slávnostnú homíliu. V súčastnosti už vnútorne drevené schodište ako aj balkón nie sú súčastou kaplnky, kedže v 80 . rokoch 20. storočia bola kaplnka komplexne zrekonštruovaná. V roku 1878 sa vybudovali kaplnky Sv. Anny a Sv. Kríža a v roku 1930 kaplnka sv. Mikuláša nad prameňom vody. V kaplnke Sv. Anny sa počas pútí slávili molebeny za zdravie a požehnanie veriacich. V kaplnke Sv. Kríža panychídy za zosnulých. Kaplnka sv. Mikuláša slúžila ako prameň vody, ktorú počas púte kňaz posvätil.?

Vplyvom púti sa postupne menilo postavenie Lutiny v cirkevných štruktúrach. Do roku 1865 bola filiálkou farnosti Hanigovce a v roku 1866 tu bolo prenesené sídlo farnosti. ${ }^{8}$

5 DANCÁk, F.: Lutina. Bazilika a hora. Prešov: Petra 2010, s. 61.

6 GüNTherová, A. (ed.): Súpis pamiatok na Slovensku. Zväzok druhý, K-P. Bratislava: Obzor, 1968, s. 267.

7 BORZA, P.: Mariánske pútnické miesto Lutina od roku 1851 dodnes. In: Mariánske pútnické miesta Prešovskej gréckokatolíckej metropolie. Zost. Jana Koprivňáková. Prešov: GTF PU 2008, s. 32.

8 Schematismus venerabilis cleri graeci ritus catholicorum dioecesis Eperiessiensis pro Anno Domini 1870, ab erecta sede episcopali Anno 50. Cassoviae: Typis Caroli Werfer, Typographi Academiae 1870, s. 45. 
Predchádzalo tomu vytvorenie zázemia pre farára. Dňa 15. júla 1865 farár z Hanigoviec Anton Rojkovič, ktorý sa o rok nato stal prvým farárom farnosti Lutina zakúpil pozemok v Lutine pri chráme sv. Kozmu a Damiána ${ }^{9}$ na výstavbu farskej budovy od Juraja Tutokyho za 55 zlatých. ${ }^{10}$ Vybudovanie farskej budovy, ktorá svojmu účelu slúži aj dnes prinieslo stálu prítomnost' kňaza $\mathrm{v}$ Lutine a prispelo k zlepšeniu podmienok aj pre prichádzajúcich pútnikov. Tí vo vel'kom množstve prichádzali do L'utiny a farnost' ako aj obec sa vzmáhala. Veriaci spolu s kňazom Antonom Rojkovičom sa v roku 1896 vybudovat nový chrám, dnes stredná čast’ Baziliky minor. Stavbu realizoval stavitel' Ján Surín, dielo malo byt dokončené už v roku 1897 pričom jeho cena bola vyčíslená na 15000 zlatých. V roku 1896 bola vyplatená záloha 5000 zlatých, d’alších 5000 zlatých malo byṫ zaplatené v roku 1897 a zvyšok po ukončení diela. V roku 1896 sa začalo s výstavbou a ešte v tom istom roku bol chrám pod strechou. ${ }^{11}$ Neskôr sa vyskytli bližšie neurčené problémy a chrám bol napokon dokončený a posvätený v roku 1903. ${ }^{12}$ Krátko predtým požiar zničil pôvodný drevený chrám.

Nový chrám bol vybudovaný v historizujúcom slohu ako jednolod’ová stavba s polygonálnym uzáverom presbytéria a do štítového priečelia vstavanou vysokou vežou. Z pôvodného vnútorného zariadenia sa do súčasnosti zachovala dominanta interiéru - štvorradový ikonostas. ${ }^{13}$ Základný rad tvoria ikony sv. Mikuláša, Matky Božej, Ježiša Krista a ikona patrocínia chrámu Narodenie Presvätej Bohorodičky.

9 Bližšie k problematike dreveného chrámu v Lutine pozri: BORZA, P.: Niekolko poznámok k zaniknutému chrámu sv. Kozmu a Damiána v Lutine. In: Theologos - teologická revue, roč. 14, 2012, č. 2, s. 185-197.

10 Halaga R. O.: Slovanské osídlenie Potisia a východoslovenskí gréckokatolíci. Košice: Východoslovenský kultúrny spolok Svojina Košice 1947, s. 112.

11 Archív Gréckokatolíckej farnosti (dalej AGF) Lutina, bez sign., Koncept zmluvy na výstavbu chrámu z roku 1896.

12 Schematizmus venerabilis cleri greaci ritus catholicorum dioecesis Eperjesiensis pro Anno Domini 1903. Eperjesini 1903, s. 91.

13 GÜNTherová, A. (ed.): Súpis pamiatok na Slovensku. Zväzok druhý, K-P. Bratislava: Obzor, 1968, s. 267. 
V súčasnosti je chrám zasvätený Zosnutiu Presvätej Bohorodičky, ale pôvodne bol zasvätený sviatku, ktorý zobrazuje ikona na ikonostase. K zmene došlo po vydaní Apoštolského bréve v roku 1988, ktorým blahoslavený pápež Ján Pavol II. povýšil miestny chrám na baziliku minor a ako patrocínium dokument uvádza sviatok Zosnutia Presvätej Bohorodičky. Medzi ikonami základného radu sú diakonské dvere s vyobrazeniami archanjelov sv. Michala a sv. Gabriela a v strede sa nachádzajú bohato zdobené královské dvere s vyobrazením evanjeliovej udalosti zvestovania Panne Márii v Nazarete. Druhý rad ikonostasu tvoria ikony dvanástich hlavných sviatkov, pričom v strede nad královskými dverami sa nachádza ikona poslednej večere. Tretí rad tvoria ikony dvanástich apoštolov, ktorým v strede tróni velkňaz Ježiš Kristus. Štvrtý rad ikonostasu predstavujú starozákonní proroci a svätí. Na vrchole ikonostasu je zobrazená Golgota t. j. Kríž s ikonami Matky Božej a apoštola evanjelistu sv. Jána.

Významné stavebné úpravy na chráme prebehli v rokoch 1981-1984. Rekonštrukcia spočívala v pokrytí veže medeným plechom a komplexnej oprave interiéru aj exteriéru. Interiér bol vyzdobený malbami akademického maliara, nositela Rádu sv. Silvestra Mikuláša Klimčáka. Z pôvodného mobiliára chrámu sa po rekonštrukcii zachoval ikonostas, svietniky pred ikonostasom a dva procesijné obrazy. Pôvodný mobiliár bol nahradený moderným nábytkom podla návrhu Ing. arch. Mariána Sitarčíka. Mikuláš Klimčák navrhol a zhotovil vitráže chrámu, mohutné vstupné dvere a vo svätyni dominantný bohostánok v podobe Kríža. ${ }^{14}$

Lutinský chrám bol postavený začiatkom dvadsiateho storočia aby poslúžil pútnikom prichádzajúcim do Lutiny uctit’ si Matku Božiu, ako aj miestnym veriacim. Zažil dve svetové vojny, nástup a pád komunizmu, zákaz a obnovu činnosti našej milovanej cirkvi. Avšak najvzácnejším dňom v jeho histórii bol 22. jún 1988, ked’ blahoslavený pápež Ján Pavol II., povýšil pútnický chrám v Lutine na Baziliku minor - Baziliku

14 BORZA, P.: Mariánska svätyňa gréckokatolíkov v Lutine. In: Dom Pána. Zost. Jerzy Brusiło, Peter Tirpák, Marek Petro. Kraków-Prešov 2011, s. 115-130. 
Zosnutia Presvätej Bohorodičky. Povýšenie prišlo v mariánskom roku, prišlo v dobe komunistického útlaku, prišlo ako mocné povzbudenie v boji za slobodu, prišlo ako neocenitelná podpora Svätého otca všetkým gréckokatolíkom v Československu. Týmto dôležitým aktom pápež potvrdil zvláštny vztah gréckokatolíkov $\mathrm{k}$ Petrovmu nástupcovi v Ríme, potvrdený mučeníckou smrtou biskupov ako aj mnohých kňazov, reholníkov a veriacich počas krutého prenasledovania $\mathrm{v}$ druhej polovici 20. storočia. Ich posilou bola aj Matka Božia, ktorú generácie gréckokatolíkov na Slovensku nežne uctievajú a vyznávajú už po stáročia. ${ }^{15}$

Rozsiahlou premenou prešla bazilika začiatkom 21. storočia $\mathrm{v}$ rokoch 2006-2009. Po jednom storočí užívania chrámu bola vážne poškodená strecha nad hlavnou lod’ou a svätyňou. Dokonca dochádzalo k zatekaniu do interiéru a hrozilo poškodenie vzácnych malieb. Preto sa v roku 2006 pristúpilo ku komplexnej rekonštrukcii, počas ktorej bola demontovaná pôvodná strecha vrátane krovu. Následne bola bazilika spevnená betonovým vencom, na ktorý stavebná firma Švestav z Brezovičky zhotovila nový krov a strechu pokryla medeným plechom. Rekonštrukcia sa v roku 2007 preniesla do nových rozmerov, ked’ z iniciatívy prešovského arcibiskupa Mons. Jána Babjaka sj sa pristúpilo k realizácii rozšírenia baziliky o dve bočné lode. Architektonický návrh pripravil Ing. arch. Viktor Tkačik a práce relaizovala firma BPS a. s. z Bardejova a v roku 2009 aj firma M-stav z Lutiny. V rokoch 2007-2009 boli vybudované dve bočné lode, opravená fasáda baziliky a vybudované malé námestie. ${ }^{16}$

Novou výstavbou sa výrazne zmenil interiér baziliky. Pôvodne jednolod’ová stavba získala trojlod’ový rozmer. Malby v pôvodnej lodi boli počas rekonštrukcie očistené od nánosov prachu a jej interiér prepojený s dvomi bočnými lod’ami. V pravej lodi baziliky bol inštalovaný

15 AGF Lutina, bez sign., Kópia dekrétu o ustanovení Baziliky minor v Lutine.

16 AGF Lutina, bez sign., Projektová dokumentácia „Obnova baziliky minor v L'utine". 
starobylý ikonostas a mobiliár z chrámu v Novej Polianke, kde sa už neslávia sv. liturgie. Pôvodne bol ikonostas súčastou dreveného chrámu v Novej Polianke a je datovaný do polovice 18. storočia. Vzácny ikonostas je dominantou bočnej lode, ktorá slúži ku každodennému sláveniu sv. liturgií pre potreby farnosti, ide vlastne o farskú kaplnku. Ikonostas a mobiliár je národnou kultúrnou pamiatkou. Obnovenú baziliku konsekroval prešovský arcibiskup a metropolita Mons. Ján Babjak SJ dňa 16. augusta 2009. Slávnosti sa zúčastnil sekretár Kongregácie pre východné cirkvi arcibiskup Mons. Cyril Vasil sj a bývalý sekretár Kongregácie pre kauzy svätých arcibiskup Mons. Edward Nowak ako aj šiesti biskupi zo Slovenska, Nemecka a Ukrajiny. Dvadsattisíc zhromaždených pútnikov ocenilo nový vzhlad baziliky, ktorý sa pre všetkých stal symbolom pozvania neustále zvelad’ovat chrám živého Boha v našom každodennom živote. ${ }^{17}$

Pri príležitosti 25. výročia vyhlásenia baziliky minor v roku 2013 pribudla do jej interiéru mozaiková výzdoba, ktorá znázorňuje sv. Jána Pavla II., blahoslavených biskupov mučeníkov Pavla Petra Gojdiča osвм, Vasila Hopka, Teodora Romžu, reholného kňaza mučeníka Metoda Dominika Trčku cssR, Božie milosrdenstvo, svadbu v Káne Galilejskej, milosrdného Samaritána a sv. Faustínu Kowalskú. Ich autorom je otec Kamil Dráb cssR. ${ }^{18}$ Neskôr k mozaikam pribudli aj vzácne relikvie svätých a blahoslavených, ktorých zobrazujú.

\section{$* * *$}

Bazilika minor v Lutine v priebehu svojej existencie prešla viacerými zmenami, ktoré zmenili jej podobu. Z pôvodne jednolodovej stavby

17 PETRíK, L.: Tisíce pútnikov prišlo do Lutiny na pút a posvícku baziliky. In: Slovo - časopis gréckokatolíckej cirkvi. 2009, roč. 41, č. 18-19, s. 7-8.

18 Petrík, L.: V Lutine si pútnici pripomenuli 25. výročie baziliky minor. In: http://grkatpo.sk/?spravy\&id=1680 [23.03.2015]. 
sa začiatkom 20. storočia rozsiahlou prestavbou stala trojlodová baziliky ukrývajúca umelecké a duchovné bohatstvo. Príčinou vzniku a premien chrámu počas uplynulého storočia až do dnešných dní bolo živé pútnické miesto a s tým spojená prítomnost’ pútnikov v Lutine. Bazilika minor ako aj okolie vd’aka ich záujmu a záujmu o nich ponúka inšpiratívne podnety $\mathrm{k}$ prehĺbeniu duchovného života a načerpaniu tvorivých síl pre každého, kto sa rozhodne L'utinu navštívit a pobudnút na tomto magickom mieste $\mathrm{v}$ lone prírody.

\section{Zoznam použitej literatúry}

Archív Gréckokatolíckej farnosti Prešov, f. Inventáre farností, inv. č. 930, Inventár farnosti Hanigovce z roku 1855.

Archív Gréckokatolíckej farnosti Lutina, bez sign., Kópia dekrétu o ustanovení Baziliky minor v Lutine.

Archív Gréckokatolíckej farnosti L’utina, bez sign., Projektová dokumentácia „Obnova baziliky minor v Lutine”.

Archív Gréckokatolíckeho arcibiskupstva Prešov, fond (dalej f) Inventáre farností, inventárne číslo (dalej inv. č.) 930, Inventár farnosti Hanigovce $\mathrm{z}$ roku 1855.

Archív Gréckokatolíckej farnosti Lutina, bez sign., Koncept zmluvy na výstavbu chrámu z roku 1896.

Schematismus venerabilis cleri graeci ritus catholicorum dioecesis Eperiessiensis pro Anno Domini 1870, ab erecta sede episcopali Anno 50. Cassoviae: Typis Caroli Werfer, Typographi Academiae 1870.

Schematizmus venerabilis cleri greaci ritus catholicorum dioecesis Eperjesiensis pro Anno Domini 1903. Eperjesini 1903.

BORzA, P.: Niekolko poznámok k zaniknutému chrámu sv. Kozmu a Damiána v Lutine. In: Theologos - teologická revue, roč. 14, 2012, č. 2, s. $185-197$. 
BORZA, P.: Mariánska svätyňa gréckokatolíkov v Lutine. In: Dom Pána. Zost. Jerzy Brusi囚o, Peter Tirpák, Marek Petro. Kraków-Prešov 2011, s. 115-130.

BORZA, P.: Mariánske pútnické miesto L'utina od roku 1851 dodnes. In: Mariánske pútnické miesta Prešovskej gréckokatolíckej metropolie. Zost. Jana Koprivňáková. Prešov: GTF PU 2008.

DANCÁK, F.: Gréckokatolícke pútnické miesta na Slovensku. Prešov: Petra 2007. DANCÁK, F.: Lutina. Bazilika a hora. Prešov: Petra 2010. Dejiny pútnického miesta Lutina. Bratislava: Novum 1991. DZURINDA, š. M.: Lucinskaja Zorja. Prešov 1946.

GüNTherová, A. (ed.): Súpis pamiatok na Slovensku. Zväzok druhý, $K-P$. Bratislava: Obzor, 1968.

Halaga R. O.: Slovanské osídlenie Potisia a východoslovenskí gréckokatolíci. Košice: Východoslovenský kultúrny spolok Svojina Košice 1947, s. 112.

PAPP, ̌̌.: Lutinská udalost'. In: Slovo - mesačník gréckokatolíkov v ČsSR. Trnava: Ssv Trnava v CN Bratislava, 1988, roč. 20, č. 8, s. 8-12. PETRÍK, L.: Tisíce pútnikov prišlo do Lutiny na pút a posvícku baziliky. In: Slovo - časopis gréckokatolíckej cirkvi. 2009, roč. 41, č. 18-19. PETRÍK, L.: V Lutine si pútnici pripomenuli 25. výročie baziliky minor. http://grkatpo.sk/?spravy\&id=1680 [23 III 2015]. 


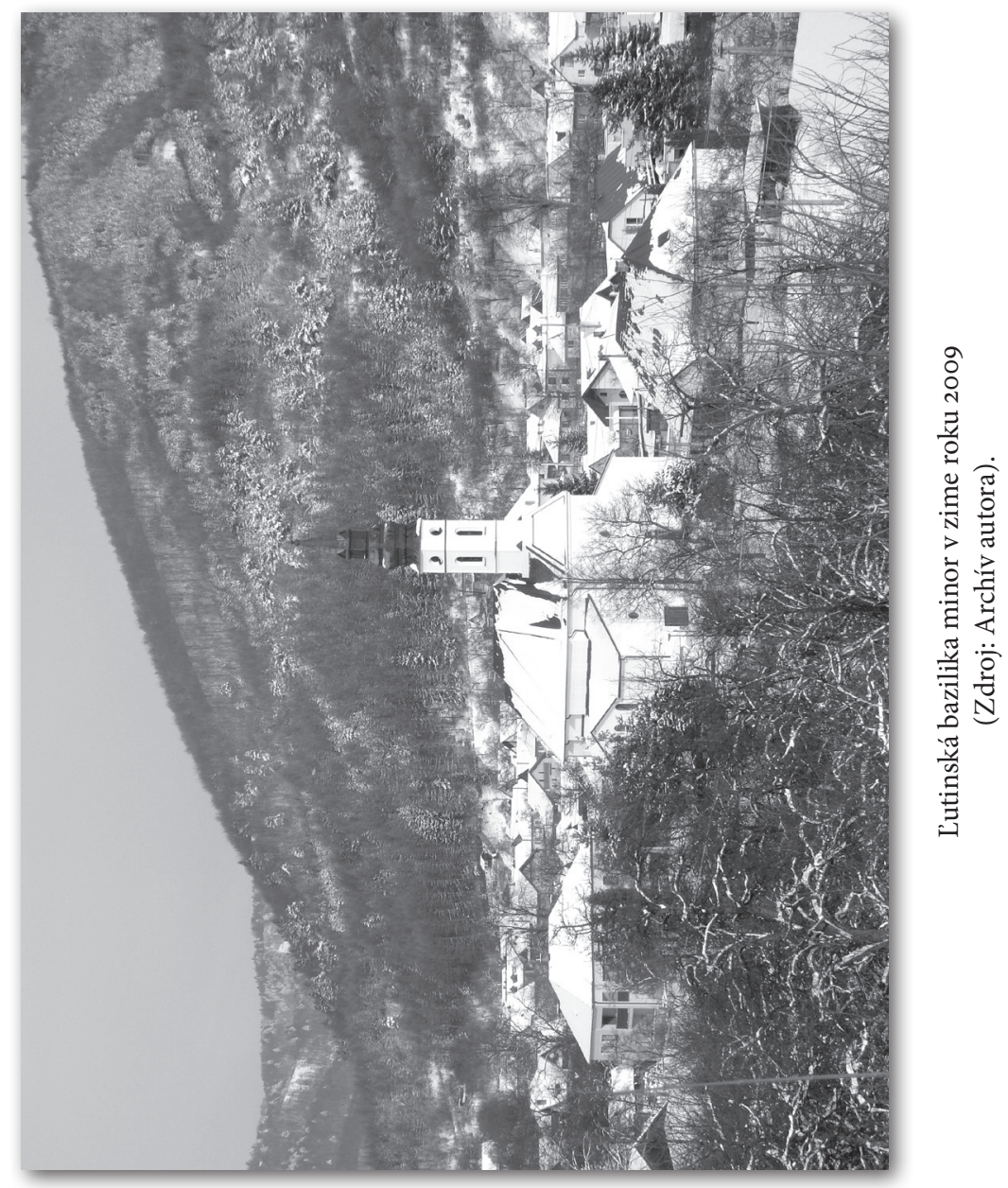




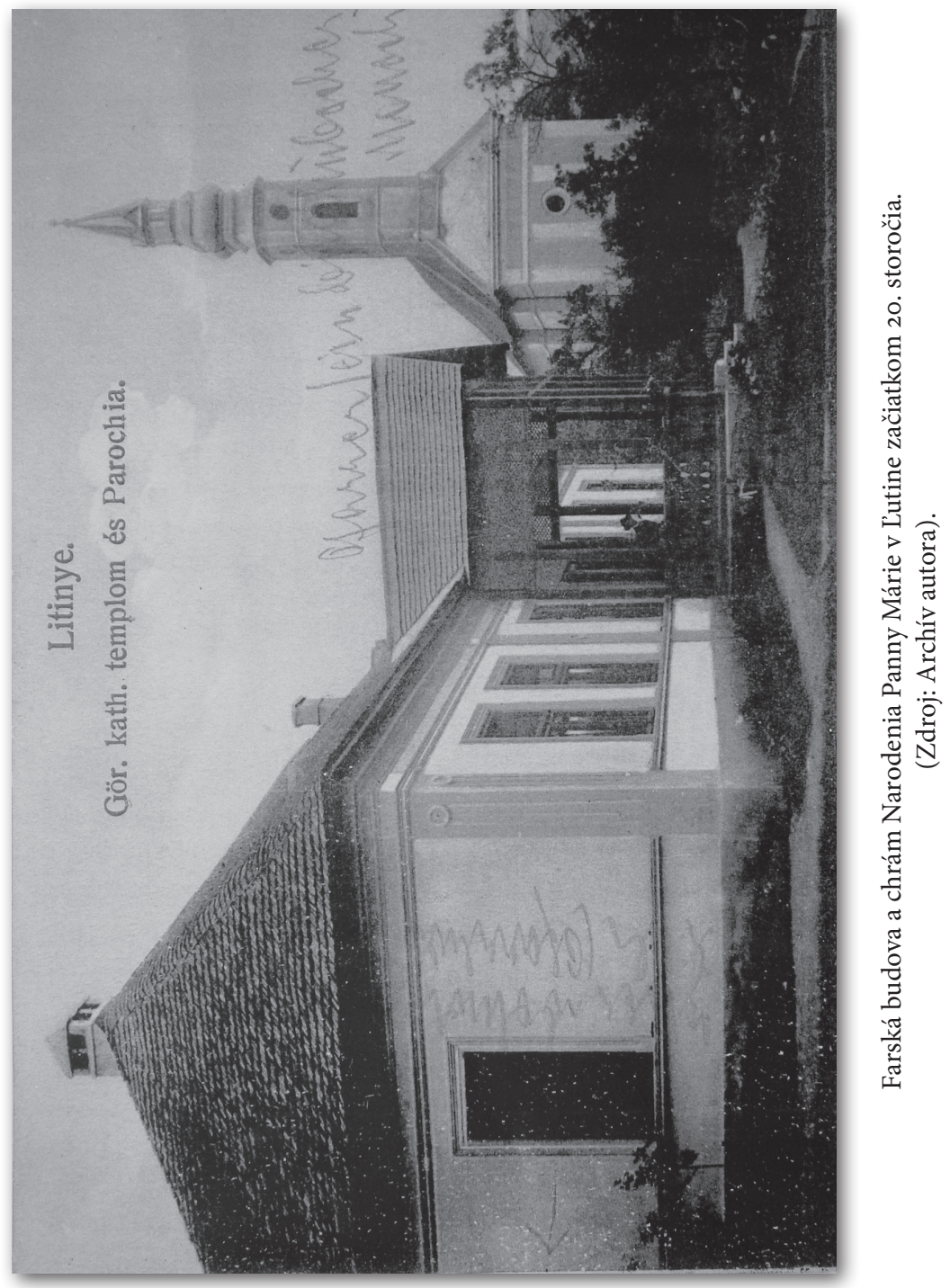




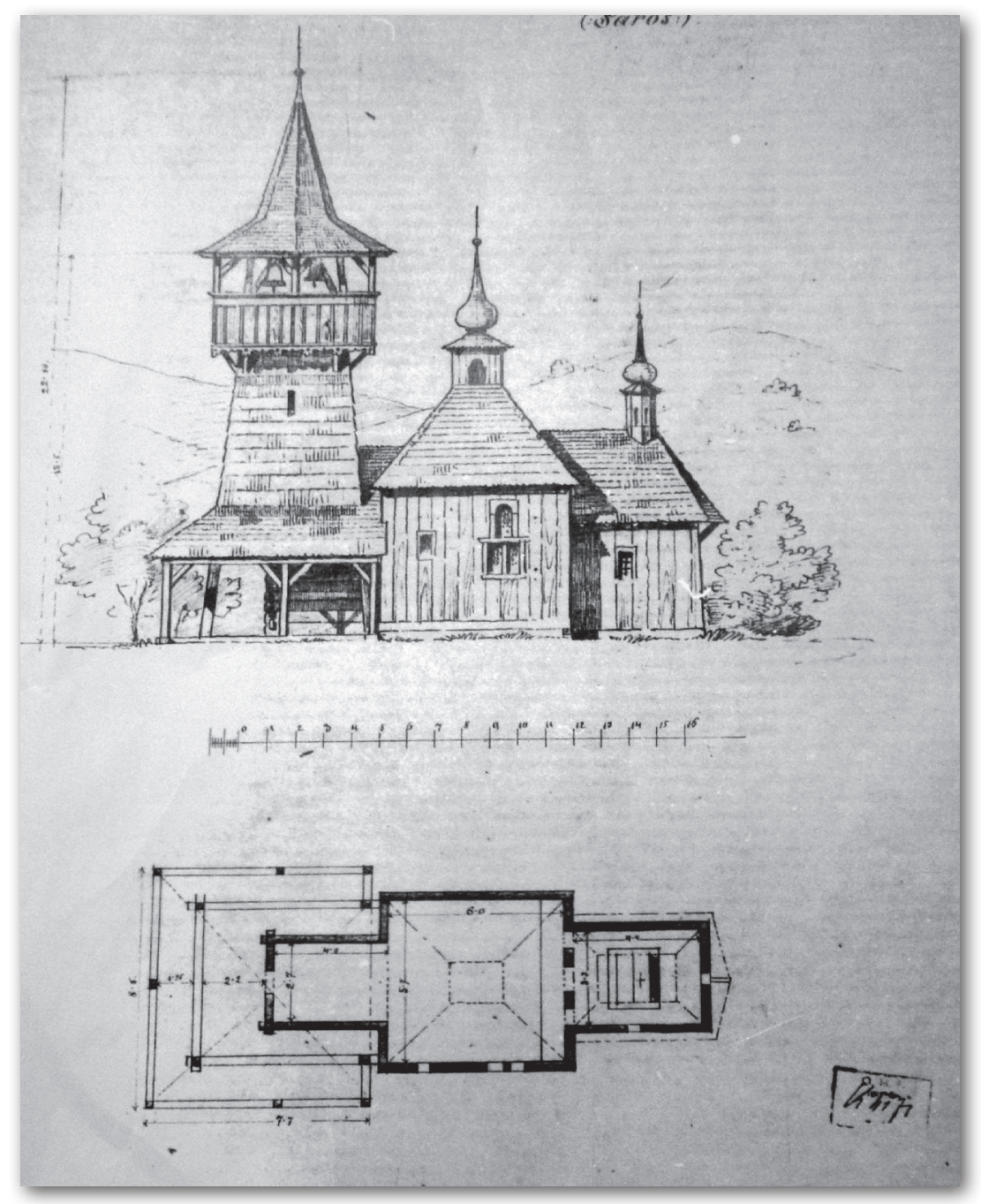

Drevený chrám sv. Kozmu a Damiána v L'utine postavený v roku 1763. (Zdroj: Archív Krajského pamiatkového úradu Prešov). 